\title{
THE RESPIRATORY, CIRCULATORY, AND NARCOTIC ANTAGONISTIC EFFECTS OF NALORPHINE, LEVALLORPHAN, AND NALOXONE IN ANAESTHETIZED SUBJECTS
}

\author{
Francts F. Foldes, M.D., Deryck DunCalF, M.B., F.F.A.H.C.S., \\ and Shigeo KuWabara, M.D."
}

IT HAS BEEN REPORTED that, when administered alone, the two clinically available narcotic antagonists, nalorphine hydrochloride (Nalline) ${ }^{1-7}$ and levallorphan tartrate, ${ }^{8-10}$ have respiratory and circulatory effects similar to those of narcotics. When a third potent narcotic antagonist, naloxone hydrochloride, became available for experimental use, it seemed worthwhile to compare the respiratory and circulatory effects of equipotent doses ${ }^{11,12}$ of these three compounds under identical conditions in man. While it obtained information of pharmacological interest, the main goal of this study was to determine which of these three compounds has the least liability to respiratory and circulatory side effects and is therefore preferable for clinical use.

\section{METHOD}

The observations to be reported were made on 50 patients without respiratory disease, who were anaesthetized for elective surgical procedures. The patients, ranging in age from 18 to 60 years, were divided at random into five groups of ten each. They received intramuscularly $100 \mathrm{mg}$ pentobarbital sodium (Nembutal) and $0.4 \mathrm{mg}$ scopolamine hydrobromide 90 and 45 minutes respectively before the start of the observation period. On arrival in the operating room, an intravenous infusion of 5 per cent dextrose containing 0.2 per cent sodium chloride was started. The patients' mouths and pharynges were topically anaesthetized with a 1 per cent tetracaine hydrochloride (Pontocaine) spray. Subsequently, all drugs were administered through the rubber sleeve of the intravenous infusion.

After determination of pulse rate, blood pressure, and respiratory rate, a "sleeping dose" of thiopental sodium (Pentothal) was administered at the rate of $25 \mathrm{mg} / 15 \mathrm{sec}$. The sleeping dose was defined as the amount required to eliminate the lid reflex and permit the insertion of an oropharyngeal airway. After the insertion of the airway, $4 \mathrm{~L}$ nitrous oxide and $1 \mathrm{~L}$ oxygen $/ \mathrm{min}$ were administered in a semiclosed system which incorporated a carbon dioxide absorber, through a wellfitting face mask. A Bennett ventilation meter was inserted in the inspiratory side of the anaesthetic circuit. After stabilization of the level of anaesthesia, which took three to five minutes, control values of pulse rate, blood pressure, respiratory rate, and minute volume were determined. Tidal volume was calculated from the minute volume and the respiratory rate.

'Division of Anesthesiology, Montefiore Hospital and Medical Center, and Department of Anesthesiology, Albert Einstein College of Medicine, Bronx, New York. 
To minimize carbon dioxide accumulation and to provide adequate oxygenation, assisted or controlled respiration was used, the latter when the subjects became apnoeic (did not breathe spontaneously for 30 seconds). For 30 seconds before and during each one-minute observation period, however, the patients were allowed to breathe spontaneously. During this time the flow rates of nitrous oxide and oxygen were each reduced to $500 \mathrm{ml} / \mathrm{min}$.

After the determination of control values of the respiratory and circulatory parameters, subjects in group I received $20 \mu \mathrm{g} / \mathrm{kg}$ oxymorphone hydrochloride (Numorphan) in 30 seconds. Those in groups II, III, and IV received in 30 seconds comparable doses of the three antagonists: ${ }^{12} 150 \mu \mathrm{g} / \mathrm{kg}$ nalorphine hydrochloride (Nalline), $20 \mu \mathrm{g} / \mathrm{kg}$ levallorphan tartrate (Lorfan), and $5 \mu \mathrm{g} / \mathrm{kg}$ naloxone hydrochloride respectively. The subjects of group $\mathrm{V}$ were given the double $(10 \mu \mathrm{g} / \mathrm{kg})$ dose of naloxone. Five minutes after the start of the injection of the narcotic antagonist, the subjects of groups II, III, IV, and V received $20 \mu \mathrm{g} / \mathrm{kg}$ oxymorphone.

The various respiratory and circulatory parameters were again determined at three minutes after the administration of the narcotic antagonists and at three, six, and ten minutes after the start of injection of oxymorphone. The respiratory parameters were observed during a one-minute period starting 30 seconds before and ending 30 seconds after the times indicated. All observations were expressed as percentages of control values. Those few cases in which partial obstruction of the airway developed were not included. In a few cases, the reservoir bag of the anaesthesia machine was replaced by a Sanborn metabolizer, and respiratory tracings were made before and after the administration of the various antagonists and oxymorphone.

\section{Results}

The intravenous administration of $150 \mu \mathrm{g} / \mathrm{kg}$ of nalorphine or $20 \mu \mathrm{g} / \mathrm{kg}$ levallorphan produced a highly significant $(p<0.001)$ decrease of the respiratory rate and minute volume in three minutes (Figs. 1 and 2; Tables I and II). The depression of the tidal volume was transient (Figs. 3 and 4), and within three minutes it returned to control value (Fig. 5 and Table III). In contrast, the administration of 5 or $10 \mu \mathrm{g} / \mathrm{kg}$ naloxone caused an insignificant change in these parameters (Figs. 1, 2, 3, and 6; Tables I, II, and III).

The circulatory effects of the three narcotic antagonists were similar and less marked. The pulse rate was decreased somewhat more by levallorphan than by the other two antagonists (Fig. 7 and Table IV). The effect of the three antagonists on systolic blood pressure, however, was about the same (Fig. 8 and Table V).

The administration of $20 \mu \mathrm{g} / \mathrm{kg}$ oxymorphone caused a highly significant ( $p<$ 0.001 ) decrease of respiratory rate, minute volume, and systolic blood pressure (Tables I and III) and a less marked but still significant $(p<0.02)$ decrease of pulse rate (Table IV). These changes were maintained throughout the tenminute observation period. 


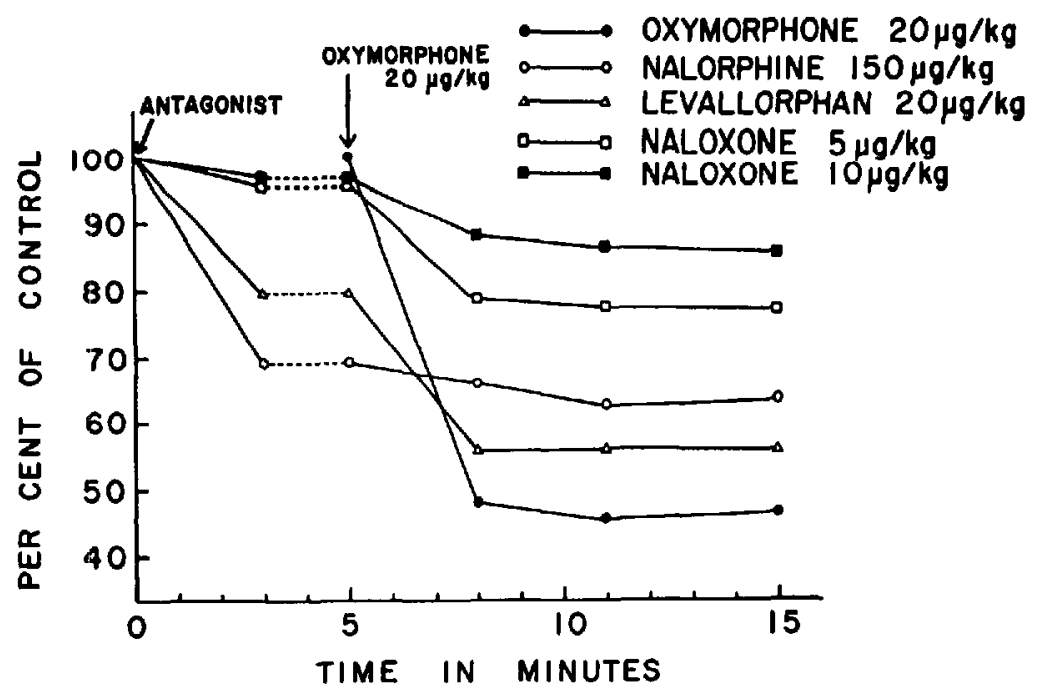

Figure 1. The influence on respiratory rates of oxymorphone alone and preceded by narcotic antagonists.

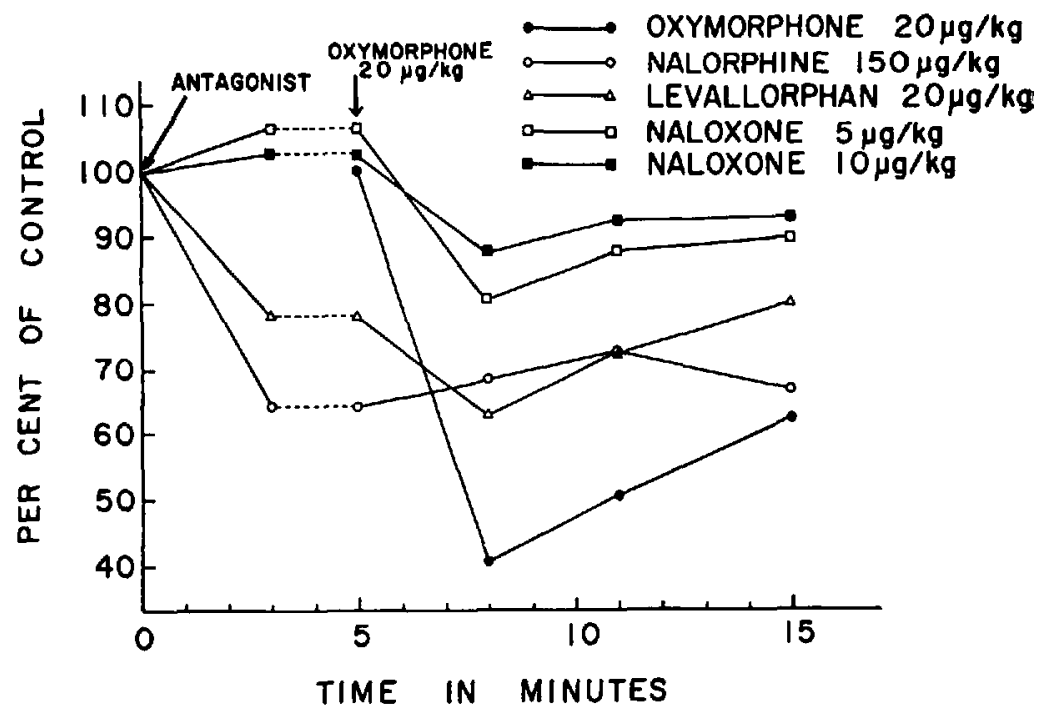

Ficure 2. The influence on minute volumes of oxymorphone alone and preceded by narcotic antagonists.

The administration of nalorphine and levallorphan five minutes before the start of injection of oxymorphone did not afford significant protection against the depression of the respiratory rate (Table I). Nalorphine $(p<0.01)$, but not levallorphan, had a significant protective effect against the depression of the minute volume. In contrast, the protective effect of both 5 and $10 \mu \mathrm{g} / \mathrm{kg}$ naloxone on the oxymorphone-induced depression of the respiratory rate $(p<0.01$ and 
TABLE I

The Effect on Respiratory Rate of Oxymorphone Alone and of Narcotic Antagonists FOLLOWED BY OXYMORPHONE

\begin{tabular}{|c|c|c|c|c|c|}
\hline \multirow[b]{2}{*}{$\begin{array}{r}\text { Time } \\
(\min t)\end{array}$} & \multicolumn{5}{|c|}{ Respiratory rates* } \\
\hline & I no antagonist & $\begin{array}{l}\text { II nalorphine } \\
150 \mu \mathrm{g} / \mathrm{kg}\end{array}$ & $\begin{array}{l}\text { III levallorphan } \\
20 \mu \mathrm{g} / \mathrm{kg}\end{array}$ & $\begin{array}{c}\text { IV naloxone } \\
5 \mu \mathrm{g} / \mathrm{kg}\end{array}$ & $\begin{array}{c}V \text { naloxone } \\
10 \mu \mathrm{g} / \mathrm{kg}\end{array}$ \\
\hline 3 & & $69.2 \pm 2.4 \ddagger$ & $79.6 \pm 2.8$ & $95.4 \pm 2.3$ & $96.7 \pm 3.4$ \\
\hline 5 & \multicolumn{5}{|c|}{$20 \mu \mathrm{g} / \mathrm{kg}$ oxymorphone administered intravenously } \\
\hline $8(3)$ & $48.0 \pm 8.5$ & $65.9 \pm 3.2$ & $55.7 \pm 3.7$ & $78.6 \pm 2.7$ & $88.1 \pm 4.3$ \\
\hline $11(6)$ & $45.3 \pm 6.2$ & $62.6 \pm 3.3$ & $55.8 \pm 3.4$ & $77.6 \pm 3.1$ & $86.4 \pm 4.5$ \\
\hline $15(10)$ & $46.3 \pm 4.0$ & $63.6 \pm 3.4$ & $55.8 \pm 3.4$ & $76.9 \pm 2.7$ & $84.1 \pm 4.4$ \\
\hline
\end{tabular}

*Expressed as per cent of control values.

†From the administration of the narcotic antagonists or oxymorphone (in parentheses). † Standard error.

TABLE II

The Effect on Minute Volume of Oxymorphone Alone and of Narcotic Antagonists FOLLOWED BY OXYMORPHONE

\begin{tabular}{|c|c|c|c|c|c|}
\hline \multirow[b]{2}{*}{$\begin{array}{r}\text { Time } \\
(\min t)\end{array}$} & \multicolumn{5}{|c|}{ Minute volumes* } \\
\hline & I no antagonist & $\begin{array}{l}\text { II nalorphine } \\
150 \mu \mathrm{g} / \mathrm{kg}\end{array}$ & $\begin{array}{l}\text { III levallorphan } \\
20 \mu \mathrm{g} / \mathrm{kg}\end{array}$ & $\begin{array}{c}\text { IV naloxone } \\
5 \mu \mathrm{g} / \mathrm{kg}\end{array}$ & $\begin{array}{c}V \text { naloxone } \\
10 \mu \mathrm{g} / \mathrm{kg}\end{array}$ \\
\hline 3 & & $64.1 \pm 4.4 \ddagger$ & $78.0 \pm 5.0$ & $106.8 \pm 6.8$ & $102.5 \pm 3.7$ \\
\hline 5 & \multicolumn{5}{|c|}{$20 \mu \mathrm{g} / \mathrm{kg}$ oxymorphone administered intravenously } \\
\hline $8(3)$ & $40.8 \pm 6.8$ & $68.5 \pm 6.5$ & $62.6 \pm 4.7$ & $80.4 \pm 4.1$ & $87.6 \pm 5.0$ \\
\hline $11(6)$ & $50.6 \pm 8.8$ & $73.8 \pm 6.4$ & $73.6 \pm 4.3$ & $87.6 \pm 4.0$ & $92.1 \pm 3.6$ \\
\hline $15(10)$ & $62.1 \pm 1.6$ & $66.8 \pm 8.1$ & $79.6 \pm 3.9$ & $89.2 \pm 3.8$ & $92.5 \pm 3.5$ \\
\hline
\end{tabular}

*Expressed as per cent of control values.

†From the administration of the narcotic antagonists or oxymorphone (in parentheses). tStandard error.

0.001 for the smaller and larger dose respectively), and the minute volume ( $p<$ 0.001 for both doses) was statistically significant (Tables I and II).

None of the narcotic antagonists influenced the slowing of the pulse rate caused by oxymorphone. The protective effect of nalorphine and naloxone against oxymorphone-induced decrease of the systolic blood pressure, however, was signifcant $(p<0.05)$ throughout the experimental period, and that of levallorphan was significant at ten minutes after the administration of oxymorphone.

\section{Discussion}

The results of the present study indicate that $5 \mu \mathrm{g} / \mathrm{kg}$ naloxone has a greater protective effect on oxymorphone-induced respiratory depression than $150 \mu \mathrm{g} / \mathrm{kg}$ nalorphine or $20 \mu \mathrm{g} / \mathrm{kg}$ levallorphan. This is in keeping with previous findings that when the same doses of these narcotic antagonists were used to counteract respiratory depression caused by five different narcotics, naloxone was the most 


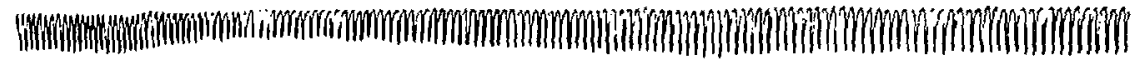

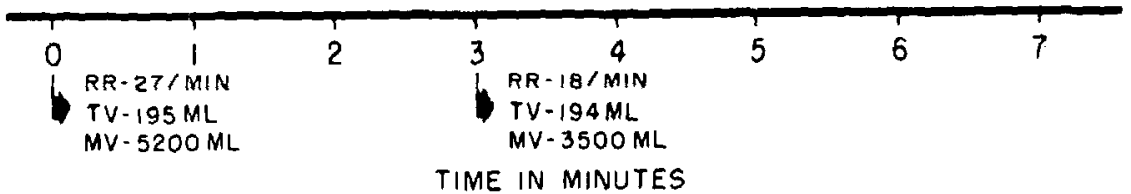

\section{remminm}

\begin{tabular}{|c|}
\hline $\begin{array}{lc}8 & 9 \\
\text { L } & \text { RR }-15 / M I N \\
T V-253 \mathrm{ML} \\
M V-3800 \mathrm{ML}\end{array}$ \\
\hline
\end{tabular}

Figune 3. The effect on respiration of nalorphine followed by oxymorphone. Note that in addition to decreasing respiratory rate and minute volume nalorphine also causes a transient diminution of tidal volume.
LEVALLORPHAN
$2 O N$ SMIKG
$\mid \begin{aligned} & \text { OXYMORPHONE } \\ & 2 O H G M / K G\end{aligned}$

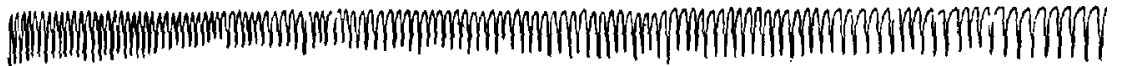

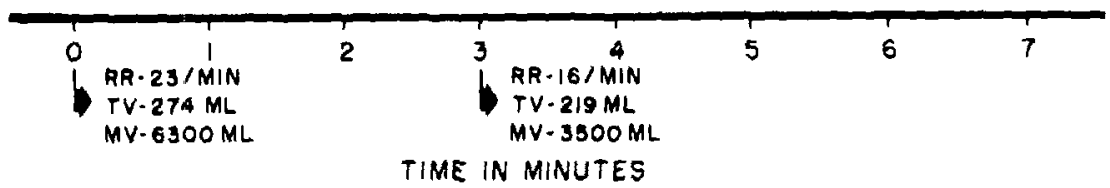

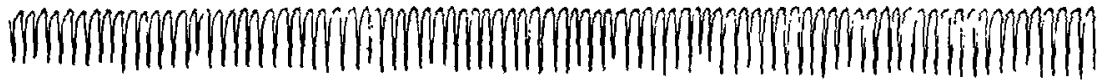

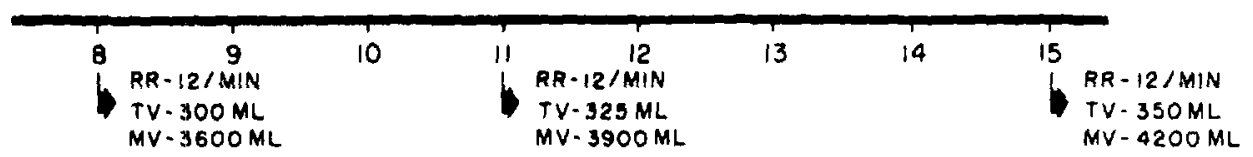

TIME IN MINUTES

Figure 4. The effect on respiration of levallorphan followed by oxymorphone. Findings are similar to those described in the legend of Figure 3. 


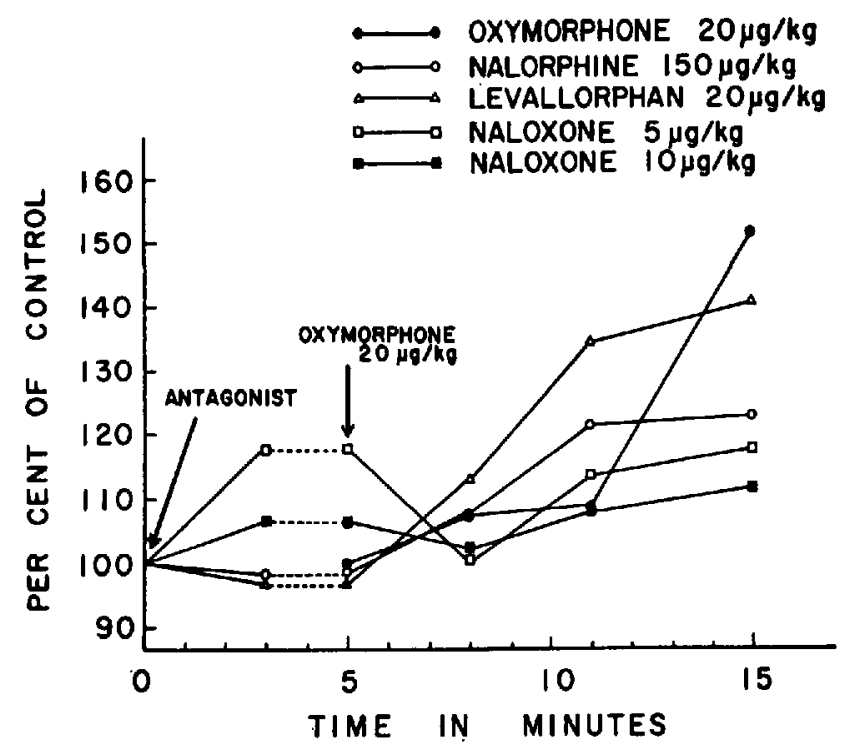

Ficure 5. The influence on tidal volumes of oxymorphone alone and preceded by narcotic antagonists.

TABLE III

The Effect on Tidal Volume of Oxymorphone Alone and of Narcotic Antagonists FOLLOWED BY OXYMORPHONE

\begin{tabular}{|c|c|c|c|c|c|}
\hline \multirow[b]{2}{*}{$\begin{array}{l}\text { Time } \\
(\min f)\end{array}$} & \multicolumn{5}{|c|}{ Tidal volumes* } \\
\hline & I no antagonist & $\begin{array}{l}\text { II nalorphine } \\
150 \mu \mathrm{g} / \mathrm{kg}\end{array}$ & $\begin{array}{l}\text { III levallorphan } \\
20 \mu \mathrm{g} / \mathrm{kg}\end{array}$ & $\begin{array}{c}\text { IV naloxone } \\
5 \mu \mathrm{g} / \mathrm{kg}\end{array}$ & $\begin{array}{c}\text { V naloxone } \\
10 \mu g / \mathrm{kg}\end{array}$ \\
\hline 3 & \multirow{2}{*}{\multicolumn{5}{|c|}{$20 \mu \mathrm{g} / \mathrm{kg}$ oxymorphone administered intravenously }} \\
\hline 5 & & & & & \\
\hline $8(3)$ & $107.3 \pm 28.9$ & $107.7 \pm 10.5$ & $113.0 \pm 2.6$ & $100.3 \pm 4.6$ & $102.3 \pm 11.2$ \\
\hline $11(6)$ & $108.7 \pm 17.7$ & $121.3 \pm 11.6$ & $134.3 \pm 6.0$ & $113.3 \pm 3.5$ & $108.0 \pm 13.0$ \\
\hline $15(10)$ & $151.7 \pm 19.1$ & $122.8 \pm 11.0$ & $140.7 \pm 6.4$ & $117.5 \pm 5.2$ & $111.6 \pm 12.5$ \\
\hline
\end{tabular}

*Expressed as per cent of control values.

tFrom the administration of the narcotic antagonists or oxymorphone (in parentheses).

IStandard error.

effective. ${ }^{12}$ Doubling the dose of naloxone (to $10 \mu \mathrm{g} / \mathrm{kg}$ ) increased the protective effect, but the increase was not statistically significant. When administered to subjects who had not received a narcotic previously, these doses of naloxone caused no respiratory depression. In contrast, under similar circumstances, doses of nalorphine $(150 \mu \mathrm{g} / \mathrm{kg})$ or levallorphan $(20 \mu \mathrm{g} / \mathrm{kg})$ commonly used to antagonize narcotic-induced respiratory depression caused a significant decrease of respiratory rate and minute volume (Tables I and II). Thus, for example, 150 $\mu \mathrm{g} / \mathrm{kg}$ nalorphine and $200 \mu \mathrm{g} / \mathrm{kg}$ morphine sulphate ${ }^{12}$ caused comparable decrease of these parameters. 
\begin{tabular}{l|l} 
NALOXONE \\
$5 \mu \mathrm{GM} / K G$
\end{tabular}$\quad\left\{\begin{array}{l}\text { OXYMORPHONE } \\
20 \mu \mathrm{GM} / K G\end{array}\right.$
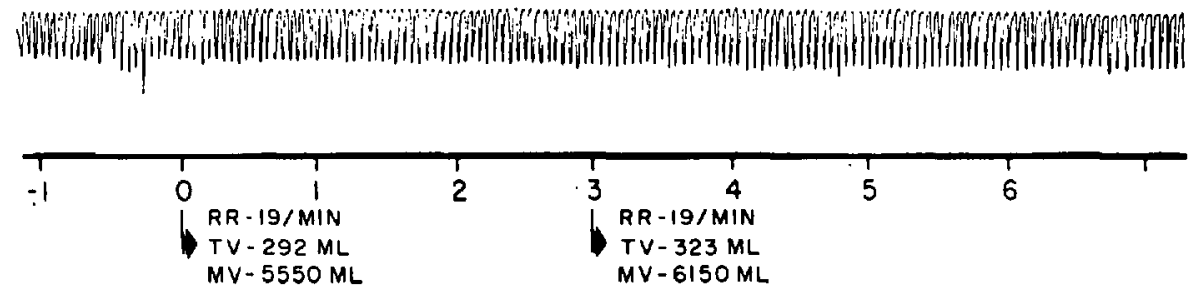

TIME IN MINUTES

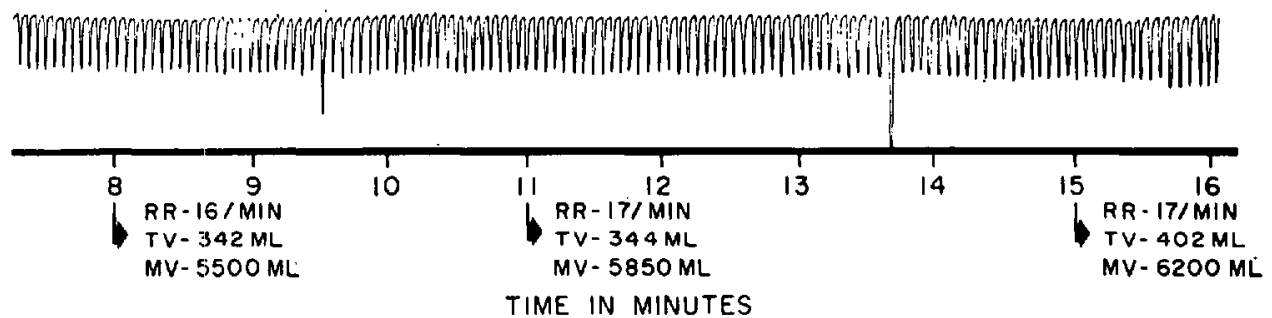

Figure 6. The effect on respiration of naloxone followed by oxymorphone. Note that in contrast to nalorphine and levallorphan, naloxone does not decrease respiratory rate, tidal volume, or minute volume.

Jasinski et al. ${ }^{13}$ observed that several pharmacologic and psychopharmacologic actions of naloxone are qualitatively different from those of nalorphine and levallorphan. Thus, in contrast to nalorphine, levallorphan, and cyclazocine, naloxone does not constrict the pupils, does not have psychotomimetic or sedative effects, and during or after chronic administration it does not cause any physiologic and behavioural changes, or physical dependence. It was also observed that naloxone retained the desirable properties of narcotic antagonists. It antagonized the effects of morphine injected one, two, and four hours after its administration and, on a $\mathrm{mg} / \mathrm{kg}$ basis, its ability to precipitate abstinence was found to be about seven times greater than that of nalorphine. On chronic administration no tolerance developed to its desirable effects.

The data summarized in Table VI indicate that naloxone possesses all the desirable therapeutic effects, and is free from the unwanted side effects of narcotic antagonists. This separation of the desirable and the undesirable effects makes naloxone the narcotic antagonist of choice for clinical use, especially when the cause of the respiratory depression is not definitely known (e.g. in the neonate whose mother has received narcotics, or in attempted suicide with an unknown central nervous system depressant). Under these circumstances, all narcotic antagonists will antagonize the respiratory depression if it is narcotic-induced. If, however, it is due to other causes, e.g. inhalation anaesthetic agents, barbiturates, 


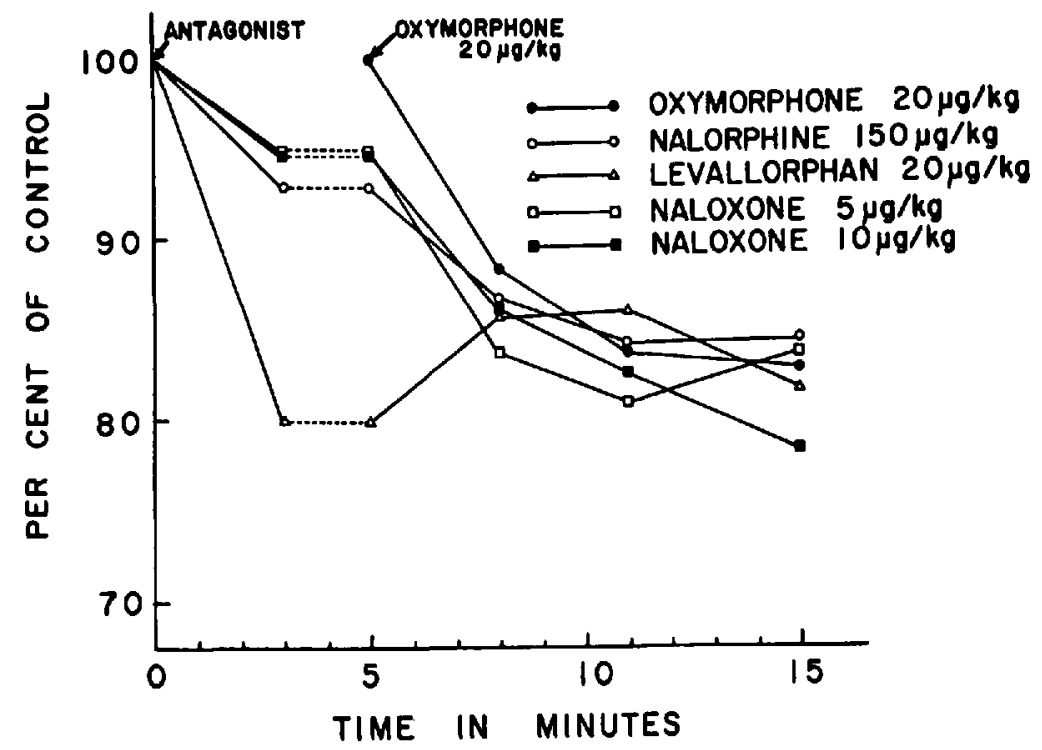

FIGURE 7. The influence on pulse rates of oxymorphone alone and preceded by narcotic antagonists.

TABLE IV

The Effect on Pulse Rate of Oxymorphone Alone and of Narcotic Antagonists Followed BY OXYMORPHONE

\begin{tabular}{|c|c|c|c|c|c|}
\hline \multirow[b]{2}{*}{$\begin{array}{c}\text { Time } \\
(\min t)\end{array}$} & \multicolumn{5}{|c|}{ Pulse rates* } \\
\hline & I no antagonist & $\begin{array}{l}\text { II nalorphine } \\
150 \mu \mathrm{g} / \mathrm{kg}\end{array}$ & $\begin{array}{l}\text { II levallorphan } \\
20 \mu \mathrm{g} / \mathrm{kg}\end{array}$ & $\begin{array}{c}\text { IV naloxone } \\
5 \mu \mathrm{g} / \mathrm{kg}\end{array}$ & $\begin{array}{c}V \text { naloxone } \\
10 \mu \mathrm{g} / \mathrm{kg}\end{array}$ \\
\hline 3 & \multirow{2}{*}{\multicolumn{5}{|c|}{$20 \mu \mathrm{g} / \mathrm{kg}$ oxymorphone administered intravenously }} \\
\hline 5 & & & & & \\
\hline $8(3)$ & $88.3 \pm 4.3$ & $86.7 \pm 3.3$ & $85.6 \pm 4.0$ & $83.6 \pm 3.7$ & $86.0 \pm 4.2$ \\
\hline $11(6)$ & $83.7 \pm 3.5$ & $84.2 \pm 3.0$ & $85.9 \pm 3.5$ & $80.8 \pm 3.8$ & $82.5 \pm 3.5$ \\
\hline $15(10)$ & $82.8 \pm 5.8$ & $84.4 \pm 2.4$ & $81.6 \pm 3.5$ & $83.6 \pm 3.0$ & $78.3 \pm 4.2$ \\
\hline
\end{tabular}

*Expressed as per cent of control values.

tFrom the administration of the narcotic antagonists or oxymorphone (in parentheses). †Standard error.

\section{TABLE $V$}

The Effect on Systolic Blood Pressure of Oxymorphone Alone and of Narcotic ANTAGONISTS FOLLOWED BY OXYMORPHONE

\begin{tabular}{|c|c|c|c|c|c|}
\hline \multirow[b]{2}{*}{$\begin{array}{l}\text { Time } \\
(\min t)\end{array}$} & \multicolumn{4}{|c|}{ Systolic blood pressures* } & \multirow[b]{2}{*}{$\begin{array}{c}V \text { naloxone } \\
10 \mu \mathrm{g} / \mathrm{kg}\end{array}$} \\
\hline & I no antagonist & $\begin{array}{l}\text { II nalorphine } \\
150 \mu \mathrm{g} / \mathrm{kg}\end{array}$ & $\begin{array}{l}\text { III levallorphan } \\
20 \mu \mathrm{g} / \mathrm{kg}\end{array}$ & $\begin{array}{c}\text { IV naloxone } \\
5 \mu \mathrm{g} / \mathrm{kg}\end{array}$ & \\
\hline 3 & \multirow{2}{*}{\multicolumn{5}{|c|}{ 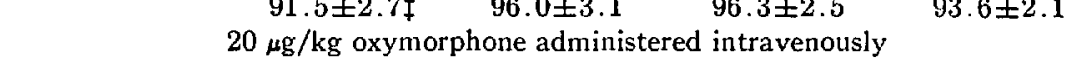 }} \\
\hline 5 & & & & & \\
\hline $8(3)$ & $80.5 \pm 2.9$ & $92.3 \pm 3.3$ & $87.3 \pm 3.0$ & $89.5 \pm 3.1$ & $90.0 \pm 2.1$ \\
\hline $11(6)$ & $80.6 \pm 3.8$ & $97.7 \pm 3.8$ & $88.2 \pm 2.0$ & $91.6 \pm 3.2$ & $88.7 \pm 1.8$ \\
\hline $15(10)$ & $78.1 \pm 3.8$ & $101.8 \pm 4.4$ & $91.5 \pm 2.4$ & $91.8 \pm 3.5$ & $89.9 \pm 1.6$ \\
\hline
\end{tabular}

*Expressed as per cent of control values.

fFrom the administration of the narcotic antagonists or oxymorphone (in parentheses). $\ddagger$ Standard error. 
FOLDES et al.: NALORPHINE, LEVALLORPHAN, AND NALOXONE

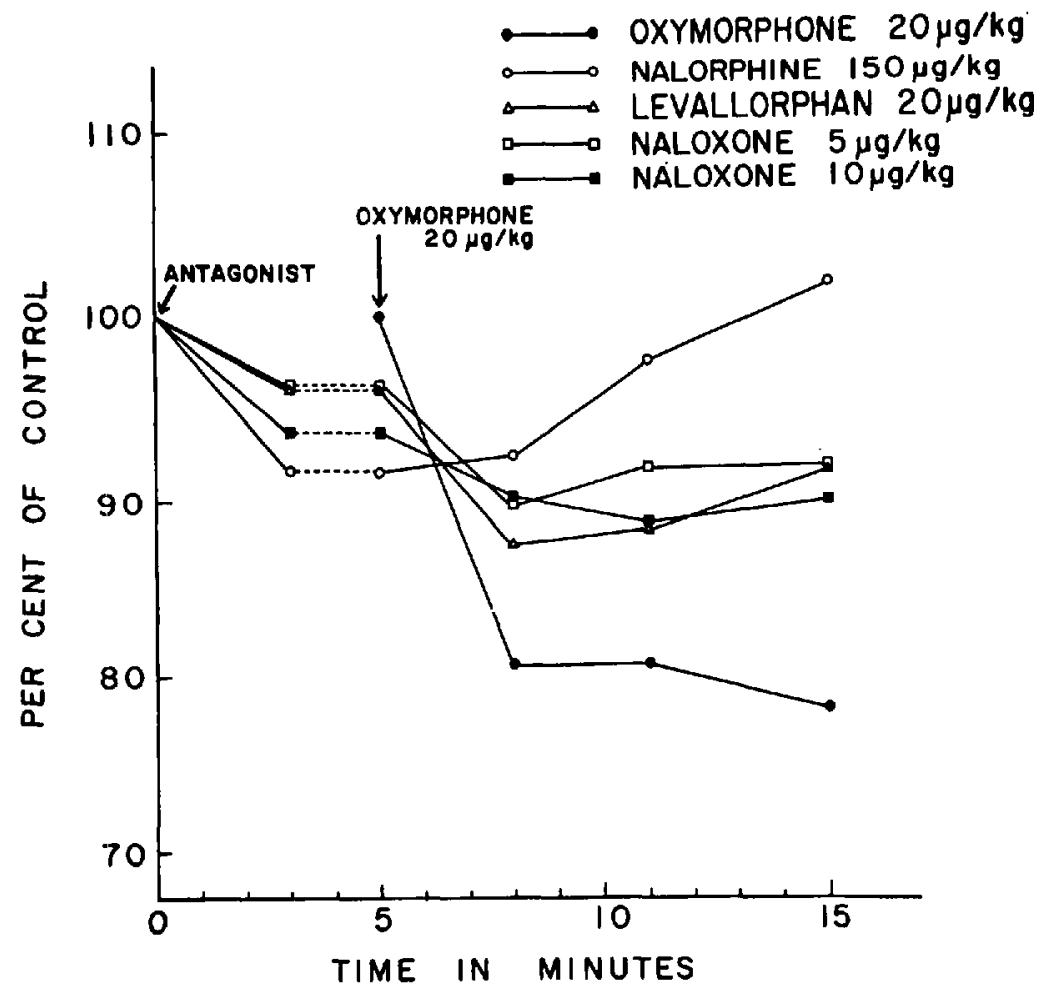

Figure 8. The influence on systolic blood pressures of oxymorphone alone and preceded by narcotic antagonists.

TABLE VI

Desirable and Undesirable Properties of Narcotic Antagonists

\begin{tabular}{lccc}
\hline & Nalorphine & Levallorphan & Naloxone \\
\hline Desirable & & & \\
antagonism of respiratory depression & $1^{*}$ & 5 & 30 \\
antagonism of circulatory depression & 1 & 5 & 30 \\
ability to precipitate abstinence & 1 & 2 & 7. \\
Undesirable & & & \\
psychotomimetic effects & yes & yes & no \\
sedation & yes & yes & no \\
pupillary constriction & yes & yes & no \\
physical dependence & yes & ? & no \\
\hline
\end{tabular}

*Relative potency on a $\mathrm{mg} / \mathrm{kg}$ basis.

hypoxia, cerebrovascular accidents, brain injury, while nalorphine and levallorphan will increase respiratory depression, naloxone will cause no further deterioration. Since doses of naloxone (170 $\mu \mathrm{g} / \mathrm{kg}$ ) up to fifteen times higher than those ( 5 to $\mathrm{J} .0 \mu \mathrm{g} / \mathrm{kg}$ ) found adequate to prevent narcotic-induced respiratory and circulatory depression had no demonstrable psychotomimetic or sedative effects in conscious subjects, it is less likely that those unwanted side effects will be encountered in patients who receive naloxone at the termination of anaesthesia. 
For the same reason, there should be no hesitation to administer repeated doses of naloxone to patients intoxicated with excessive doses of narcotic analgesics.

\section{SUMMaRY}

Nalorphine $(150 \mu \mathrm{g} / \mathrm{kg})$ and levallorphan $(20 \mu \mathrm{g} / \mathrm{kg}$ ), when administered to lightly anaesthetized subjects who had not received a narcotic, caused significant depression of respiratory rate and minute volume. In contrast, 5 and $10 \mu \mathrm{g} / \mathrm{kg}$ naloxone caused no respiratory depression. These doses of nalorphine, levallorphan, and naloxone caused a moderate decrease of pulse rate and systolic blood pressure. Naloxone 5 and $10 \mu \mathrm{g} / \mathrm{kg}$ offered significantly greater protection against the respiratory depressant effects of $20 \mu \mathrm{g} / \mathrm{kg}$ oxymorphone administered five minutes later than $150 \mu \mathrm{g} / \mathrm{kg}$ nalorphine or $20 \mu \mathrm{g} / \mathrm{kg}$ levallorphan. None of the three narcotic antagonists affected the oxymorphone-induced decrease of pulse rate, and all had about the same protective effect against the fall of systolic blood pressure caused by this compound. Since doses of naloxone, which provide significantly better protection against narcotic-induced respiratory depression than the conventional doses of nalorphine and levallorphan, cause no respiratory depression in themselves, it should be considered the narcotic antagonist of choice for clinical use.

\section{RÉSUMÉ}

La nalorphine $(150 \mu \mathrm{g} / \mathrm{kg})$ et la levallorphan $(20 \mu \mathrm{g} / \mathrm{kg})$, administrés à des sujets sous anesthésie légère et qui n’avaient pas reçu de narcotique, ont produit une dépression marquée du rythme respiratoire et du volume minute. Par contre, 5 et $10 \mu \mathrm{g} / \mathrm{kg}$ de naloxone n'ont pas causé de dépression respiratoire. Ces doses de nalorphine, de levallorphan et de naloxone ont produit une diminution modérée de la fréquence cardiaque et de la pression sanguine systolique. Cinq et dix $\mu \mathrm{g} / \mathrm{kg}$ de naloxone ont donné une bien meilleure protection contre la dépression respiratoire produite par $20 \mu \mathrm{g} / \mathrm{kg}$ d'oxymorphone, administrés cinq minutes après, que $150 \mu \mathrm{g} / \mathrm{kg}$ de nalorphine ou $20 \mu \mathrm{g} / \mathrm{kg}$ de levallorphan. Aucun de ces trois antagonistes des narcotiques n'a modifié le ralentissement du pouls provoqué par l'oxymorphone et tous ont exercé a peu près le même effet protecteur contre la chute de pression systolique produite par ce médicament.

Puisque des doses de naloxone, qui produisent une protection réellement meilleure contre la dépression respiratoire consécutive aux narcotiques que ne le font les doses ordinaires de nalorphine et de levallorphan, ne produisent par ellesmêmes aucune dépression respiratoire, il faudrait considérer ce produit (naloxone) comme l'antagoniste de choix des narcotiques pour usage clinique.

\section{REFERENCES}

1. Ecrenhoff, J. E.; Elder, J. D., JR.; \& King, B. D. N-allyl-normorphine in the Treatment of Morphine or Demerol Narcosis. Am. J. Med. Sc. 223: 191 (1952).

2. Eckenhoff, J. E. \& Oech, S. R. Effects of Narcotics and Antagonists upon Respiration and Circulation in Man. Clin. Pharmacol. Therap. 1: 483 (1960).

3. Fraser, H. F.; Van HorN, C. D.; \& IsbelL, H. Studies on N-allyl-normorphine in Man: Antagonism to Morphine Sulfate and Heroin and Effects of Mixtures of N-allylnormorphine and Morphine. Am. J. Med. Sc. 231: 1 (1956).

4. Hugcins, R. A.; Spencer, W. A.; Geddes, L. A.; Deavers, S.; \& Moyer, J. H. Respiration Functions in Man Following Intravenous Administration of Morphine, $\mathrm{N}$-allylnormorphine, and $\mathrm{N}$-allyl-morphine after Morphine. Arch. Internat. Pharmacodyn. 111: 275 (1957). 
5. Lasagna, L. \& BeEcher, H. K. Analgesic Effectiveness of Nalorphine-morphine Combinations in Man. J. Pharmacol. Exper. Therap. 112: 356 (1954).

6. Salomon, A.; Marcus, P. S.; Herschrus, J. A.; \& Segals, M. S. N-allyl-normorphine (Nalline) Action on Narcotized and Non-narcotized Subjects. Am. J. Med. 17: 214 (1954).

7. Tenney, S. M. \& Mithoefer, J. C. The Respiratory Depressant Action of N-allyl-normorphine in the Normal Subject and in Patients with Respiratory Acidosis Secondary to Pulmonary Emphysema. New England J. Med. 249: 886 (1953).

8. Schwab, M.; Becker, H. M.; Koppen, E.; Podworny, M.; \& Wagnen, P. H. Der Einfluss des Morphin-Antagonisten (-)-N-Allyl-3-hydroxymorphinan auf die normale und die durch (-)-N-Methyl-3-hydroxymorphinan und morphin gehemmte Atmung des gesunden Menschen. Arzneimittel-Forsch. 7: 283 (1957).

9. Swerdlow, M. Levallorphan: Effects of Large Doses. Anaesthesia. 13: 318 (1958).

10. Thomas, D. V. \& TenneY, S. M. Effect of Levorphan and Levallorphan on the Respiratory Mechanism of Normal Man. J. Pharmacol. Exper. Therap. 113:250 (1955).

11. Foldes, F. F.; Shapira, M.; Torda, T. A. G.; Duncalf, D.; \& Shiffman, H. P. Studies on the Specificity of Narcotic Antagonists. Anesthesiology. 26:320 (1965).

12. Foldes, F. F. \& Tonda, T. A. G. Comparative Studies with Narcotics and Narcotic Antagonists in Man. Acta Anaesth. Scandinav, 9: 121 (1965).

13. Jasinski, D. R.; Martin, W. R.; \& Haertzen, C. A. The Human Pharmacology and Abuse Potential of N-allyl-noroxymorphone (Naloxone). J. Pharmacol. Exper. Therap. 157: 420 (1967). 